\title{
HUBUNGAN TINGKAT PENGETAHUAN DENGAN KEPATUHAN DIET PADA PASIEN GAGAL GINJAL KRONIK YANG DILAKUKAN HEMODIALISIS REGULER DI RUMAH SAKIT DARMO SURABAYA
}

\author{
Sri Sumilati*, Umdatus Soleha** \\ Fakultas Keperawatan dan Kebidanan \\ Universitas Nahdlatul Ulama Surabaya Jl. Smea 57 Surabaya \\ Email: umdatus@unusa.ac.id
}

\begin{abstract}
One of the therapies for the patients with chronic kidney failure is diet. In fact, the sufferers sometimes give less participation on the diet. One of the factors is the patient's knowledge about diet. Therefore, the purpose of this study was to find out the correlation between the knowledge level and the diet obedience level in the patients with chronic kidney failure having regular hemodialysis in Darmo Hospital. The design of study was analytic-observational. The population involved all of the patient with chronic kidney failure having regular hemodialysis in Darmo hospital. totally 63 people, in which 54 respondents were taken as the samples by using simple random sampling technique. The data were collected by using a questionnaire. The independent variable was the knowledge, whereas the dependent one was the diet obedience. Moreover, the data analysis was done by using Mann-Whitney's test with the significance level $\alpha=0.05$. The result of study showed that most of the respondents (59\%) had high level of knowledge, whereas nearly all of them (83.3\%) were obedient with their diet. Furthermore, the result of analysis showed that $p=0.220$ so that $p>\alpha$ which meant that there was no significance correlation between knowledge and diet obedience. The conclusion of study was that the knowledge was not the main factor of the diet obedience. There are other supporting factors, such as experiences in having hemodialysis therapy that can affect someone to go on a diet. Hence, the nurses and their family should play a role more actively in giving counseling about the diet for chronic kidney failure.
\end{abstract}

\begin{abstract}
Abstrak: Salah satu terapi pada pasien gagal ginjal kronik adalah diet, namun pada kenyataan penderita gagal ginjal kronik terkadang kurang berpartisipasi dalam melakukan diet, salah satu faktornya adalah pengetahuan pasien tentang diet. Tujuan penelitian ini adalah mengetahui hubungan tingkat pengetahuan dengan tingkat kepatuhan diet pada pasien gagal ginjal yang hemodialisis regular di Rumah Sakit Darmo. Jenis penelitian ini adalah analitik observasional populasinya semua pasien gagal ginjal kronik yang dilakukan hemodialisis regular di Rumah Sakit Darmo sebesar 63 orang, besar sampel 54 responden yang diambil menggunakan simple random sampling. Pengumpulan data menggunakan kuesioner, variabel independent pengetahuan dan variabel dependent kepatuhan diet. Data dianalisis dengan uji statistik Mann Whitney, dengan kemaknaan $\alpha=$ 0,05 . Hasil penelitian menunjukkan bahwa sebagian besar (59\%) responden mempunyai pengetahuan baik dan hampir seluruhnya $(83,3 \%)$ responden patuh dalam melakukan diet, hasil analisis didapatkan $\rho=0,220, \rho>\alpha$ artinya tidak ada Hubungan yang bermakna antara pengetahuan dan kepatuhan diet. Simpulan dari penelitian ini adalah pengetahuan bukanlah faktor utama terhadap kepatuhan diet seseorang, ada faktor lain yang mendukungnya seperti pengalaman dalam menjalani terapi hemodialisis dapat mempengaruhi seseorang dalam melakukan diet. Peran perawat dan keluarga diharapkan lebih aktif dalam memberikan penyuluhan tentang diet gagal ginjal kronik.
\end{abstract}

Kata kunci: pengetahuan, kepatuhan diet, pasien gagal ginjal kronik 


\section{PENDAHULUAN}

Pasien dengan penyakit ginjal kronik, dapat menyerang pada setiap orang baik, pria maupun wanita tanpa memandang status ekonomi. Gejala gagal ginjal jika diketahui sedini mungkin, penderita bisa mendapat bantuan unuk mengubah atau menyesuaikan gaya hidupnya sedini mungkin yaitu dengan diet. Gagal ginjal pada umumnya dapat diklasifikasikan berdasarkan klasifikasi stadium ditentukan oleh nilai laju filtrasi glomerulus, yaitu stadium yang lebih tinggi menunjukkan nilai laju filtrasi glomerulus yang lebih rendah. Klasifikasi tersebut membagi penyakit ginjal kronik. Gagal ginjal yang dapat terdeteksi sejak dini dapat memberikan kemudahan bagi pasien untuk mudah sembuh, tetapi berdasarkan fakta yang ada masih banyak pasien dengan gagal ginjal sulit untuk disembuhkan bahkan meningkat dari stadium satu ke stadium diatasnya yang menyebabkan sulitnya penyembuhan. Hal tersebut di dasarkan pada kenyataan kurangnya partisipasi pasien gagal ginjal yang mengikuti anjuran diet gagal ginjal yang dianjurkan oleh dokter, seperti porsi makanan yang disediakan pasien gagal ginjal kronik yang terkadang masih utuh, dengan melakukan makan dari luar yang tidak sesuai diet gagal ginjal kronik.

Menurut pendapatnya Roesli (2008) secara etiologi penyebab gagal ginjal disebabkan oleh glomerulonefritis (25\%), diabetes melitus (23\%), hipertensi (20\%) dan ginjal polikistik (10\%). Dari data dinas kesehatan Surabaya juga menunjukkan jumlah kunjungan pasien gagal ginjal secara umum di rumah sakit dan puskesmas terus meningkat yaitu sejak 2011 yang terdiri dari 477 kunjungan tahun 2012 ada 350 kunjungan dan tahun 2013 hingga bulan Mei 2013 sudah tercatat 398, Rusdi (2013). Sedangkan data rekam medik Rumah Sakit Darmo yang kami peroleh pada tahun 2011 terapat 45 orang menjalani hemodialisis regular dengan kunjungan 250 kunjungan perbulan, meningkat 20 \% di tahun 2013 dan di tahun 2014 pada bulan januari sampai Maret 2014 mencapai 63 orang dengan jumlah kunjungan 450 tiap bulannya.

Berdasarkan survei awal pada bulan Mei 2014 dari 10 orang yang dilakukan hemodialisis regular diperoleh hasil 6 orang $(60 \%)$ tidak patuh terhadap diet yang dianjurkan dan 4 orang $(40 \%)$ patuh terhadap diet yang dianjurkan.

Menurut Brunner \& Suddarth (2002) Intervensi diet diperlukan pada gangguan fungsi renal yang mencakup pengaturan yang cermat terhadap masukan protein, masukan cairan untuk mengganti caran yang hilang, masukan natrium untuk menggantikan natrium yang hilang dan pembatasan kalium . Faktor yang membentuk tindakan konservatif berdasarkan sikap pasien terhadap penyembuhan gagal ginjal kronik dapat berupa pengaturan diet makanan berupa protein, natrium, cairan dan kalium. Pasien dengan ketidak patuhan diet gagal ginjal kronik seringkali memberikan dampak yang tidak baik, yang pada kinerja ginjal.

Salah satu upaya yang dapat membantu pasien dalam pelaksanaan diet gagal ginjal dapat dilakukan berupa penatalaksanaan pasien gagal ginjal. Intervensi diet akan memberikan pengaruh yang dibutuhkan terhadap masuknya protein, masuknya cairan untuk mengganti natrium yang hilang, dan pembatasan kalium. Maka dari itu diet gagal ginjal perlu adanya pemberian motivasi serta pengembangan informasi pada perawat sebagai tim kesehatan dalam melaksanakan diet gagal ginjal. Maka 
perlu adanya penyuluhan khususnya pada keluarga terhadap status diet gagal ginjal pada pasien gagal ginjal kronik yaitu dengan memberikan pemahaman tentang pentingnya diet melalui metode penyuluhan terhadap pasien gagal ginjal kronik.

Dari uraian latar belakang maka peneliti tertarik untuk melakukan penelitian tentang hubungan tingkat pengetahuan dengan tingkat kepatuhan diet pada pasien gagal ginjal yang hemodialisis di Rumah Sakit Darmo.

Sedangkan glomerulonefritis sekunder apabila kelainan ginjal terjadi akibat penyakit sistemik lain seperti diabetes melitus, lupus eritematosus sistemik (LES), mieloma multipel, atau amiloidosis (Prodjosudjadi, 2006).

Gambaran

klinik glomerulonefritis mungkin tanpa keluhan dan ditemukan secara kebetulan dari pemeriksaan urin rutin atau keluhan ringan atau keadaan darurat medik yang harus memerlukan terapi pengganti ginjal seperti dialisis (Sukandar, 2006).

a. Diabetes melitus

Menurut American Diabetes Association (2003) dalam Soegondo (2005) diabetes melitus merupakan suatu kelompok penyakit metabolik dengan karakteristik hiperglikemia yang terjadi karena kelainan sekresi insulin, kerja insulin atau keduaduanya.

Diabetes melitus sering disebut sebagai the great imitator, karena penyakit ini dapat mengenai semua organ tubuh dan menimbulkan berbagai macam keluhan. Gejalanya sangat bervariasi. Diabetes melitus dapat timbul secara perlahan-lahan sehingga pasien tidak menyadari akan adanya perubahan seperti minum yang menjadi lebih banyak, buang air kecil lebih sering ataupun berat badan yang menurun. Gejala tersebut dapat berlangsung lama tanpa diperhatikan, sampai kemudian orang tersebut pergi ke dokter dan diperiksa kadar glukosa darahnya (Waspadji, 2006).

b. Hipertensi

Hipertensi adalah tekanan darah sistolik $\geq 140 \mathrm{mmHg}$ dan tekanan darah diastolik $\geq 90 \mathrm{mmHg}$, atau bila pasien memakai obat antihipertensi (Mansjoer, 2001). Berdasarkan penyebabnya, hipertensi dibagi menjadi dua golongan yaitu hipertensi esensial atau hipertensi primer yang tidak diketahui penyebabnya atau idiopatik, dan hipertensi sekunder atau disebut juga hipertensi renal (Sidabutar, 2008).

c. Ginjal polikistik

Kista adalah suatu rongga yang berdinding epitel dan berisi cairan atau material yang semisolid. Polikistik berarti banyak kista. Pada keadaan ini dapat ditemukan kista-kista yang tersebar di kedua ginjal, baik di korteks maupun di medula. Selain oleh karena kelainan genetik, kista dapat disebabkan oleh berbagai keadaan atau penyakit. Jadi ginjal polikistik merupakan kelainan genetik yang paling sering didapatkan. Nama lain yang lebih dahulu dipakai adalah penyakit ginjal polikistik dewasa (adult polycystic kidney disease), oleh karena sebagian besar baru bermanifestasi pada usia di atas 30 tahun. Ternyata kelainan ini dapat ditemukan pada fetus, bayi dan anak kecil, sehingga istilah dominan autosomal lebih tepat dipakai daripada istilah penyakit ginjal polikistik dewasa (Suhardjono, 2004).

\section{METODE PENELITIAN}

Jenis penelitian adalah analitik observasional. Analitik observasional bertujuan untuk menguji hipotesis 
mengenai hubungan antar variabel (Nursalam, 2009), sedangkan menurut waktunya, pendekatan yang digunakan adalah cross sectional karena mengamati variable independen dan variable dependen hanya satu kali dalam periode yang sama.

Populasi penelitian ini adalah semua pasien gagal ginjal kronik yang dilakukan hemodialisasi regular di Rumah Sakit Darmo sebanyak 63 orang. Sampel dalam penelitian ini adalah sebagian pasien gagal ginjal kronik yang dilakukan hemodialisa regular di Rumah Sakit Darmo. Besar sampel yang diambil dalam penelitian ini 54 yang diambil dengan cara pengambilan sampel (sampling) simple random sampling.

Lokasi penelitian ini dilaksanakan di Rumah Sakit Darmo. Adapun alasan pemilihan lokasi penelitian ini adalah masih terdapat pasien gagal ginjal kronik yang tidak patuh dalam berdiet.

Penelitian ini dilaksanakan bulan Juli 2014. Variabel dependent (tergantung). Variabel dependent dalam penelitian ini adalah kepatuhan diet pada pasien gagal ginjal kronik.

Pengumpulan data dalam penelitian ini menggunakan data primer yang diperoleh melalui kuesioner. Kuesioner memuat data khusus dan data umum. Data umum terdiri dari 6 soal, data khusus 10 soal tentang pengetahuan dan 5 soal yang tertuang dalam checklist tentang kepatuhan diet gagal ginjal kronik.

Pengumpulan data dimulai dengan cara mengajukan surat pengambilan data awal kepada institusi pendidikan setelah memperoleh surat pengambilan data awal, peneliti mengajukan persetujuan kepada Kepala Ruang HD Rumah Sakit Darmo. Untuk melakukan penelitian, lebih dahulu meminta izin peneliti dengan memberikan kuesioner tanpa memberi nama responden tentang sejauh mana hubungan pengetahuan dengan kepatuhan diet pada pasien gagal ginjal kronik yang dilakukan hemodialisasi regular di Rumah Sakit Darmo. sampel yang digunakan dalam penelitian diambil sebagian pasien gagal ginjal kronik yang dilakukan hemodialisasi regular di Rumah Sakit Darmo.

Dalam penelitian ini menggunakan data primer. Data primer adalah data yang diperoleh dari hasil pengisian kuesioner oleh responden dengan menjawab pertanyaan dari kuesioner yang telah disiapkan untuk mengukur variabel independen sedangkan untuk mengukur variable dependen peneliti melakukan observasi diet gagal ginjal kronik. Kedua data tersebut diambil dari setiap responden dengan melakukan hanya observasi 1 kali.

Analisis data dilakukan melalui tabulasi data, kemudian dianalisis dengan tabel distribusi frekuensi dan dilakukan tabulasi silang untuk mengetahui hubungan pengetahuan tentang gagal ginjal kronik dengan kepatuhan diet pada pasien gagal ginjal kronik yang dilakukan hemodialisasis di Ruang HD Rumah Sakit Darmo.

Untuk mencari hubungan antara vaiabel independen (pengetahuan pasien gagal ginjal kronik) dengan variabel dependen (kepatuhan diet gagal ginjal kronik), dianalisis melalui uji statistik mann whtney dengan nilai kemaknaan $\alpha=0,05$. Apabila hasil uji statistik $\mathrm{p}<0,05$ berarti H0 ditolak yang artinya ada hubungan antara variabel yang diukur.

\section{HASIL}


Hasil penelitian menunjukkan bahwa dari 54 responden atau sebagian besar $(59 \%)$ responden memiliki pengetahuan baik.

Karakteristik responden berdasarkan tingkat kepatuhan diet, menunjukkan bahwa dari 54 responden hampir seluruhnya $(83,3 \%)$ klien gagal ginjal patuh dalam menjalankan diet gagal ginjal kronik. Responden yang mempunyai pengetahun baik didapatkan hampir seluruhnya $(87,5 \%)$ patuh menjalankan diet gagal ginjal kronik, dari 13 responden yang berpengetahuan cukup didapatkan hampir seluruhnya $(84,6 \%)$ patuh menjalankan diet, dari 9 responden yang berpengetahuan kurang didapatkan sebagian besar $(66,7 \%)$ patuh dalam menjalankan diet gagal ginjal kronik.

Berdasarkan hasil uji statistik Mann Whitney dengan $\alpha=0,05$ didapatkan nilai signifikansi $=0,220$ sehingga didapatkan $\rho>0,05$ sehingga H1 ditolak, dengan demikian dapat ditarik kesimpulan bahwa tidak ada hubungan yang bermakna antara pengetahuan dengan kepatuhan diet pada pasien gagal ginjal kronik yang mendapat terapi hemodilisis regular di Rumah Sakit Darmo.

\section{PEMBAHASAN}

Faktor yang dapat mempengaruhi pengetahuan seseorang yaitu usia, pendidikan, pekerjaan. Usia responden sebagian berusia 50 tahun. Usia sangat berpengaruh terhadap pengetahuan seseorang, karena pada usia yang sangat dewasa akan semakin banyak pengetahuan yang dimiliki dan memiliki motivasi kuat keinginannya untuk sembuh agar penyakit mereka tidak berlanjut ke stadium yang lebih tinggi.
Menurut Nursalam (2003) berpendapat bahwa semakin bertambah usia seseorang maka pengetahuan mereka bertambah karena pengetahuan bukan hanya berasal dari lingkungan maupun tingkat pendidikan tetapi pengalaman mereka dalam menghadapi realita kehidupan.

Hampir setengah responden pekerja swasta dari berbagai bidang. Sehingga seseorang yang memiliki pekerjaan akan memperoleh informasi dari berbagai pihak, khususnya tentang pengetahuan gagal ginjal kronik dan pantangan yang harus dipatuhi. Menurut pendapat Nursalam (2001) berpendapat bahwa umumnya seseorang yang bekerja cenderung mempunyai pengetahuan yang cukup baik dari pada yang tidak bekerja. Hal ini disebabkan karena orang di lingkungan kerja merupakan sumber informasi yang dapat menambah pengetahuan seseorang selain media elektronik..

Hampir setengahnya responden berpendidikan menengah. Pengetahuan tidak hanya diperoleh dari pendidikan saja, akan tetapi pengalaman juga berperan penting terhadap pengetahuan yang diperoleh seseorang. Menurut Nursalam (2001) tidak dapat dipungkiri bahwa jika seseorang tingkat pendidikannya tinggi maka semakin mudah pula pengetahuan yang di miliki. Walaupun pendidikan tidak tinggi akan tetapi mempunyai pengalaman yang banyak akan mempengaruhi pengetahuan itu sendiri.

Hampir seluruhnya $(83,3 \%)$ klien gagal ginjal patuh dalam menjalankan diet gagal ginjal kronik. Hal ini terjadi karena klien memiliki kesadaran pentingnya patuh terhadap diet gagal ginjal kronik agar penyakit mereka tidak berlanjut ke stadium yang 
lebih tinggi.

Kepatuhan diet gagal ginjal pada umumnya didasarkan oleh pendapatnya Mereda, (2007) yaitu kecenderungan untuk mengikuti order yang diberikan oleh figure ahli. Faktor yang memepengaruhi pasien gagal ginjal kronik dalam menjalankan diet selain usia, pendidikan dan pekerjaan ada faktor lain diantaranya ekonomi, pengalaman, psikologis, keluarga.

Responden berumur lebih dari 50 tahun, umur sangat berpengaruh terhadap kepatuhan seseorang, karena pada umur yang sangat dewasa akan semakin banyak pengalaman yang didapatkan yang mempengaruhi hasil dari kepatuhan dan kuat keinginannya untuk sembuh agar penyakit mereka tidak berlanjut ke stadium yang lebih tinggi.

Hasil uji statistik Mann Whitney dengan bahwa tidak ada hubungan yang bermakna antara pengetahuan dengan kepatuhan diet pada pasien gagal ginjal kronik yang mendapat terapi hemodilisis regular di Rumah Sakit Darmo.

Berdasarkan fakta tersebut, dapat dinyatakan bahwa pengetahuan bukanlah faktor utama yang berhubungan dengan kepatuhan menjalankan diet gagal ginjal kronik, sehingga tinggi rendahnya pengetahuan seseorang tidak akan mempengaruhi kepatuhan diet pasien gagal ginjal kronik karena masih ada faktor lain yang perlu diperhatikan seperti kondisi ekonomi, pengalaman pasien mengidap gagal ginjal kronik, faktor psikologis dan dukungan keluarga.

Hal tersebut sesuai dengan yang dikemukakan Muhammad (2003), perilaku manusia merupakan hasil dari pada segala macam pengalaman serta interaksi manusia dengan lingkungannya yang terwujud dalam bentuk pengetahuan, dan tindakan.

Kondisi ekonomi sangat erat kaitannya dengan status kesehatan, karena semakin tinggi keadaan ekonomi seseorang maka akan semakin mudah orang tersebut mematuhi ataupun melanggar diet gagal ginjal kronik, namun sebaliknya bila semakin rendah keadaan ekonomi seseorang maka akan mudah baginya untuk mematuhi diet gagal ginjal kronik. Penderita gagal ginjal kronik yang sudah puluhan kali menjalani terapi hemodialisis cenderung patuh terhadap diet gagal ginjal kronik karena mereka sudah memahami pengaruh dan efek bila mereka tidak patuh terhadap diet gagal ginjal kronik yang dapat mengakibatkan meningkatnya stadium gagal ginjal kronik yang dapat berpengaruh pada faktor psikologis mereka seperti rasa kurang percaya diri dan emosi, peran keluarga sangat penting dan berpengaruh pada pasien gagal ginjal kronik dalam menjalankan kepatuhan diet gagal ginjal kronik dalam bentuk dukungan moril, selalu menyertai dan memberi semangat yang tinggi dapat menjadi pemicu kepatuhan pasien gagal ginjal kronik dalam menjalankan dietnya.

\section{KESIMPULAN}

1. Pasien gagal ginjal kronik yang mendapat terapi hemodialisis regular di Rumah Sakit Darmo sebagian besar memiliki pengetahuan baik tentang diet gagal ginjal kronik.

2. Pasien gagal ginjal kronik yang mendapat terapi hemodialisis regular di Rumah Sakit Darmo hampir seluruhnya patuh pada diet gagal ginjal kronik.

3. Tidak ada hubungan yang bermakna antara pengetahuan tentang diet dan 
kepatuhan diet gagal ginjal kronik pada pasien yang mendapat terapi hemodialisis regular di Rumah Sakit Darmo

\section{DAFTAR PUSTAKA}

Almatsier, Sunita. (2006). Penelitian Diet Edisi Baru. Jakarta, Gramedia pustaka utama.

Arikunto, Suharmini. 2006. Proses Penilitian Suatu Pendekatan Praktik. Jakarta: Rineka Cipta

Chonchol (2005). Dalam kutipan kutipan jurnal ilmiah gagal ginjal skripsi tidak dipublikasikan for pdf. universitas Sumatra utara diakses 28 Mei 2014 jam 10.00 wib Prodjosudjadi, 2006

Dinkes Jatim (2013). Ketersediaan Data Kesehatan Masyarakat Provinsi Jawa Timur. $\underline{\text { www.alfredsaleh.files.wordpres }}$ s.com

Kusumawati (2009). kutipan jurnal ilmiah gagal ginjal skripsi tidak dipublikasikan for pdf. universitas Sumatra utara diakses 28 Mei 2014 jam 10.00 wib Prodjosudjadi, 2006

Kuswandi (2004).Hipertensi The Silent Killer.Jakarta: Yayasan Penerbitan Ikatan Dokter Indonesia

Mereda.2007.Kepatuhan(PerilakuMan usia).http://www.citcat.com/cc?i $=\mathrm{http} \% 3 \mathrm{~A} \% 2 \mathrm{~F} \% 2 \mathrm{Fen}$. wikipedia. org\%2Fwiki\%2FObedience_\%28 human_behavior\%29\&v=qPOJj5 511. Diakses tanggal 21 Agustus 2010 Jam 14.00 WIB.

Mubarok (2007). Promosi Kesehatan Sebuah Pengantar Proses Belajar Mengajar Dalam Pendidikan. Yogyakarta, Graha Ilmu.

National Kidney Foundation, 2009. kutipan jurnal ilmiah gagal ginjal skripsi tidak dipublikasikan for pdf. universitas Sumatra utara diakses 28 Mei 2014 jam 10.00 wib

Niven, Neil. 2002. Psikologi Kesehatan:Pengantar Untuk Perawat dan Profesional Kesehatan Lain. Jakarta: EGC

Noer, 2006. kutipan jurnal ilmiah gagal ginjal skripsi tidak dipublikasikan for pdf. universitas Sumatra utara diakses 28 Mei 2014 jam 10.00 wib

Notoatmodjo, Soekidjo (2005). Metodologi Penelitian Kesehatan, Jakarta, Rineka Cipta

Nursalam (2009). Konsep dan Penerapan Metodologi Penelitian Ilmu Keperawatan. Salemba Medika. Jakarta.

Perazella, 2005,kutipan jurnal ilmiah gagal ginjal skripsi tidak dipublikasikan for pdf. universitas Sumatra utara diakses 28 Mei 2014 jam 10.00 wib

Regina Gracieella 2002. Diet Sehat. Jakarta

Rekam Medik RS Darmo Surabaya, 2014.

Roesli, 2008 kutipan jurnal ilmiah gagal ginjal skripsi tidak dipublikasikan for pdf. universitas Sumatra utara diakses 28 Mei 2014 jam 10.00 wib Prodjosudjadi, 2006.

Soegondo (2005). Roesli, 2008 kutipan jurnal ilmiah gagal ginjal skripsi tidak dipublikasikan for pdf. universitas Sumatra utara diakses 28 Mei 2014 jam 10.00 wib Prodjosudjadi, 2006

Suhardjono, 2004. Kutipan jurnal ilmiah http://askep-askeb.cz.cc/ Jumat, 13 Mei 2011. Diakses tanggal 28 Mei 2014

Sukandar, 2006. kutipan jurnal ilmiah 
$\begin{array}{lcc}\text { gagal ginjal } & \text { skripsi tidak } \\ \text { dipublikasikan } & \text { for } & \text { pdf. }\end{array}$ universitas Sumatra utara diakses 28 Mei 2014 jam 10.00 wib

Suprajitno (2004). Asuhan

Keperawatan Keluarga. EGC.

Jakarta.

Supriasa (2001). kutipan jurnal ilmiah gagal ginjal skripsi tidak dipublikasikan for pdf. universitas Sumatra utara diakses 28 Mei 2014 jam 10.00 wib Prodjosudjadi, 2006

Waspadji (2006). Dalam kutipan jurnal ilmiah gagal ginjal skripsi tidak dipublikasikan for pdf. universitas Sumatra utara diakses 28 Mei 2014 jam 10.00 wib Prodjosudjadi, 2006 